\title{
Importance of environment quality in sustainable tourism destinations: the young tourists' perception
}

\author{
Tania Florentina Pîrghie', Elena Matei*1 \\ ${ }^{1}$ University of Bucharest, Romania
}

In the framework of sustainable development, the tourist industry demand increases in rigorousness and must pay more attention to environmental quality. In this context, this study aims to analyse the perception and attitude of the Young Generation of Tourists (YGT) regarding environmental quality, one direction in sustainable tourist destinations. The objectives of research focus on analysing the perception regarding environmental issues in vacation destinations, in order to identify how strongly is the YGT oriented towards sustainable tourism, followed by testing their pro-environmental behavioural profile. The study used the survey method applying the questionnaire as a tool, processed in SPSS V 27. The results show that young Romanians have a proenvironmental perception regarding the quality of most environmental components (air, water, vegetation). The perception is in line with their behaviour which demonstrates their awareness of the need to carry out tourist activities in modern, sustainable conditions, which affect the environment as little as possible. We also found that the YGT's involvement in environmental actions in tourist areas is limited.

Key Words: perception, attitude, YGT, environment quality, sustainable tourism

Article Info: Received: August 29, 2020; Revised: September 21, 2020; Accepted: September 30, 2020; Online: November 30, 2020.

\section{${ }^{*}$ Corresponding author}

Address: Department of Human and Economic Geography, Faculty of Geography, University of Bucharest, N. Bălcescu Av., no. 1, Bucharest, 010041, Romania

Phone: +4021.3143508 | Email: elena.matei@g.unibuc.ro

(C)2020 Human Geographies; The authors 


\section{Introduction}

In 2007, when Romania was admitted to the EU, the European Community Commission officially launched the Agenda for a sustainable and competitive European tourism (COM, 2007). Since then, the EU has pursued the implementation of these policies, among which the creation of instruments for measuring sustainable tourism at destinations, named ETIS toolkit (2013; Matei, 2016). In this last document, several criteria refer to tourists' environmental impact on destinations. In this respect, many Romanian tourist areas are affected by the past (Levei et al., 2009; Filip \& Cocean, 2012) or current pollution (Nuta et al., 2015). Among the present environmental issues, Romania is affected by air pollution (gas, material particles, noise), caused mainly by road traffic (Bucharest, Constanța) (Iordache et al., 2013; Oncioiu et al., 2020); soil pollution by heavy metals and waste, especially domestic (Ungureanu et al., 2018) which damage water bodies and landscape (Romcea et al., 2018; Breban, 2019). It is also well known that the reduction of forested areas by illegal logging (Petrișor, 2015; Dumitrașcu et al., 2020) facilitates the spread of invasive plants (Doroftei \& Anastasiu, 2014; Matei, 2018). These environmental issues fall primarily under the jurisdiction of the Ministry of Environment (ME), but also of the Ministry of Tourism (MT). These two institutions must collaborate for the creation and operation of sustainable tourist destinations, where environmental quality is only one of their four dimensions. So far, MT has published a tourism strategy for the period 2013-2026 (Nicula et al., 2013), but as far as sustainable tourism is concerned, there are only segments of strategies divided by types of tourism, such as ecotourism (Teodorov et al., 2020).

Statistically, tourism does not have a massive impact on the environment. Thus, a simple analysis of the tourist flow in Romania, which in 2019 amounted to 13 million tourists (National Institute of Statistics - INS, 2020), means that tourist pressure, computed as a ratio between the number of tourists and the residents in the localities with tourist functions, is on average small $(0.7$ tourists/inhabitant). However, some areas have a ratio of 3/1 (Brașov, Constanța, Prahova counties) or even $10 / 1$ in the summer season on the Black Sea Coast (Matei, 2016). The pressure exerted by the flow size, corroborated with the behaviour of tourists and stakeholders in various destinations towards environmental quality, shows that there are areas with a risk of pollution and hence the need to take pro-environmental and pro-sustainability measures at a national and local level. In tourism, consumer behaviour by age, education, income, must be analysed in-depth to understand the root of the issue, as well as the tourists' expectation and measures needed to meet them. Buffa (2015) discusses a long-term perspective of the next generations of young tourists and argues the need to understand the trends that highlight a rising interest in the sustainability dimension of tourism, often connected with an authentic tourism experience, so as to ensure its coherent development in the future.

The YGT, also known as the millennials cohort, which consists of people born between 1981-2000 (Reeves \& Oh, 2008), who access digital services before, 
during and after consumption (Nusair et al., 2011), undergoes several formative experiences that influence their travels, perceptions and attitude (Gardiner et al., 2014). In Romania, this segment represents approximately $27 \%$ of the total population, which means that, theoretically, from the flow of domestic tourists recorded in 2019, this cohort would amount to about 1.8 million people (INS, 2020). That is almost $20 \%$ of the total number of tourists. Taking into account this statistical aspect alone, corroborated with the pollution issues presented above, the analysis of the perception and attitude of the YG consumer about the environmental quality in destinations could help define the strategies for sustainable tourism in Romania.

The concept of sustainability in tourism as a subject of research increased in recent years. Many studies start from or debate some aspects found in the concept of sustainable tourism defined by OMT and UNEP (2005), as "tourism that takes full account of its current and future economic, social and environmental impact, addressing the needs of visitors, industry, environment and host communities" (Nafi \& Ahmed, 2017: 74). Lu \& Nepal (2009) identify five areas of study in sustainable tourism: tourism impact; sustainability assessment; development; behaviour and attitude of the visitor; and planning. On the other hand, Buckley (2012) concludes that the four most popular thematic areas of sustainable tourism are ecotourism, responsible tourism, community tourism and conservation tourism. Other investigations deal with case studies, empirical studies and critical reviews, but the topics and themes mature over time (Ruhanen et al., 2015). Nafi \& Ahmed (2017) emphasise the need to promote sustainable development in all tourism sectors and address specific principles that can help reduce tourists' negative impact and preserve the natural environment, as well as the built-up one, considered an alternative to mass tourism. In order to study how sustainable tourism works, some researchers approach the subject going from theory to practice (Barkely, 2012) or from policies and strategies towards society (Bramwelland Lane, 2010; Scheyvens, 2011), while others tackle it from consumer to the paradigm of sustainable development (Budeanu, 2007; Nicholas \& Thapa, 2010). As far as the research on the perceptions and attitudes of tourists belonging to generation $\mathrm{Y}$ on the quality of the environment in tourist destinations is concerned, there is a scarcity in topics and approaches. Nafi \& Ahmed (2017) stated that only a few studies focus on the tourist market made up of young people and on their perceptions and attitudes regarding the development of sustainable tourism. Of these, Jennings et al. (2010) stand out. These authors highlight the appetite of the young generation for qualitative tourist experiences and the cleanliness level of accommodation spaces.

In the Romanian scientific literature, Matei et al. (2019) deem that there is a deficit of research on the profile, perception and attitudes of the YG regarding domestic tourism, which entails the need to study the tourism phenomenon from the perspective of this consumer segment. The publications dedicated to the YG are few, and their topics are not very diverse. Thus, Gavreliuc \& Ciobotă (2013) analysed the role that Romanian society has on the attitudes and 
behaviours of young people. Băbăiță et al., (2010) studied tourists' perception about hospitality services in Romania and other EU countries, noting that young tourists see as disadvantages of services at destination: staff's lack of professionalism, the fact that any complaint is considered an insult, staff shortage, as well as insufficient cleanliness. Manea et al. (2013) focus on voluntourism, as a form of sustainable tourism, and consider that volunteer tourists in Romania are young people with the following qualities: friendly, responsible, educated, adaptable, and with initiative; attracted by new experiences in authentic places, and caring for people and nature. Matei et al. (2019) find in the YG's perception an orientation towards natural attractions or outdoor activities in the Romanian Carpathians destinations.

On this background, the aim of the study is to analyse the perception and attitude of the YGT about the environmental elements specific to tourist destinations, in order to identify a series of directions that tourism could follow, coupled with the needs of both this cohort and sustainable development. The research hypotheses are the following: the YGT is strongly oriented towards sustainable tourism; the socio-demographic structure influences the prosustainability perception of tourism; the perception of sustainable tourism is more robust in the female population; young people with university and postgraduate studies are more aware of the negative impact of mass tourism; the YGT has a pro-environmental behavioural profile.

\section{Methods and research design}

The perception was analysed using the survey method. Thus, a semi-structured questionnaire was applied online, using the snowball technique, in March 2020, a period largely overlapping with the first lockdown in Romania due to the COVID-19 pandemic. The digital dissemination also acknowledged the skills of the YGT, known to be a consumer of IT products (Puisard et al., 2011). These two factors led to the predominance of female respondents (two thirds), an aspect closely related to the configuration of the specific channels employed by the questionnaire operator, but also to the greater willingness of this gender to respond in such surveys (Matei et al., 2019).

On the final sample of 245 respondents, the average age is 23.5 years, structured as the following: $77 \%$ under 24 years old, $2 \%$ over 35 years, and $21 \%$ between 25 and 34 years. The marital structure is probably related to age, as $87 \%$ of the interviewees have not started a family. As an occupation, most are students (42\%), while the rest in the sample have university degrees. Given the significant share of participants under the age of 23 , who are likely to study and work part-time, a one-fifth share of those with incomes of around 150Euro is normal. Those with incomes between 350Euro and 650Euro have the highest share $(38 \%)$, while those who earn between 650Euro and 1250Euro represent one fifth. The questionnaire included six questions, meant to test the perception of the target group about the importance given to on environmental aspects in 
tourist destinations. The closed questions were focused on assessing the importance that cohort members attach to some aspects of environmental quality, based on the three-step Likert scale, where 1 stands for "low importance", 2 for "medium importance" and 3 for "high importance". The same type of scale was used to assess the attitudes/behaviours in the sustainability consumption process. In this case, the value 1 was chosen for the answer "never", 2 for "sometimes", and 3 for "always". An open question which measured the degree of involvement of the respondents if they noticed environmental problems was also included. For all variables, the Cronbach's Alpha is good (0.762). The data were processed in SPSS Statistics v. 20 by quantitative research: descriptive statistics (frequency), the independent T-test, Anova Fisher test, and the graphs utilities.

\section{Results and discussions}

\section{The YGT perception of the role of environmental quality when selecting a} vacation destination

Starting from the assertion that the environment offers a set of tourism resources deriving both from natural and anthropogenic components, through the aesthetic, cultural, energy and food services, their sustainable harnessing within the hospitality industry must aim at maintaining the quality of the ecosystems' functionality. In this sense, the study analysed the perceptions of tourists about: air pollution, noise, water quality, biosphere quality and polluting elements of the landscapes (invasive plants and waste soil pollution) in a destination. At the same time, two synthesis elements were added, namely the quality of landscaped scenery and a tourist' "for" or "against" environmental behaviour.

The independent T-test results show that there is a statistical difference between males and females for all variables $(p<0.05)$, but Cohen's $d$ value is less than 0.2, which translates into a small effect (Cohen, 1992). The Fisher Anova test, on a 95\% confidence interval, respectively, with $\mathrm{p}<0.05$, is valid only for some demographic and variable characteristics (Table 1).

Table 1. Perception of GYT on environmental quality in destinations. The relevant results of $F$, and $p<0.05$ in tests.

\begin{tabular}{llll}
\hline \multicolumn{1}{c}{ Items } & $\begin{array}{c}\mathrm{F}(\text { Laven/ } \\
\text { Fisher Test) }\end{array}$ & $\begin{array}{c}\text { Value } \\
\mathrm{p}<0.05\end{array}$ & \multicolumn{1}{c}{ Type of analysis } \\
\hline Clean waters & 9.693 & 0.002 & Independent simple T-test \\
No garbage & 9.735 & 0.002 & (gender) \\
No invasive plants & 3.909 & 0.049 & \\
No noise & 4.235 & 0.041 & \\
Clean air & 6.444 & 0.012 & \\
Fine landscape quality & 5.028 & 0.026 & \\
Lack of invasive plants & 4.141 & 0.043 & One-Way Anova (marital status) \\
Clean air & 4.963 & 0.027 & One-Way Anova (income) \\
\hline Source Selected from
\end{tabular}

Source: Selected from IBM output, SPSS v 20 
Therefore, in order to ensure the study's relevance, the graphs were applied by grouping variables using frequency. The results show, globally, a strong orientation of respondents towards the environment. Thus an aversion towards visible street litter in the chosen destination stands out $(84.9 \%)$, a considerable need for clean air $(85.7 \%)$ and waters $(66.1 \%)$. The perception regarding invasive plants, which is a problem in tourist destinations reveals that $40 \%$ of respondents gave them medium importance, while $39.6 \%$ of high importance. In the case of noise pollution, $60 \%$ of the respondents are disturbed by it to a high degree, and $30 \%$ see it as acceptable. All these aspects converge-with the general perception $(70 \%)$ for clean, unpolluted landscape in destinations.

The more in-depth analysis of the gender differences in perception shows that females greatly worry for all environmental components quality. Males are concerned more about noise pollution, while for all other variables, they are equally divided between low and moderate values (Figure 1).

By educational background, perception shows similarity in rating the environmental variables for those with secondary studies as low and moderate except for air quality, which is seen as very significant for a destination. As far as those with higher education, they have an equally divided perception of all value levels and all variables. The group with postgraduate studies is dissatisfied moderately to high about all the environmental aspects, but mostly about noise pollution and the spread of invasive plants, which could be linked with a longer formative route (Figure 1).

The perception according to age shows a structure that covers all rating scale for 18-24 group, compared to those aged over 35 years who are highly disturbed by the presence of waste, water and air pollution in destinations.

The noise pollution is perceived as very disturbance especially in the case of the older group of YGT, probably related to the presence of children in their families, compared to people aged under 35 years old, for whom noise is less annoying, a group characterised by a higher tolerance degree

Considering their marital status, married people put particular emphasis on the quality of the environment; they particularly appreciate the lack of invasive plants in the destination they visit. This perception could be explained by the fact that married people usually have a larger family with more than one child, who are more sensitive to the effects induced by some plants on the respiratory system or who experience physical discomfort due to other plants (Matei, 2018).

The financial status introduces some differences in terms of perception. Thus, low-income population perceives that air quality and lack of litter must play a more significant role in choosing a vacation destination, while people with higher incomes appreciate the nicety landscape as a sum of a clean environment (Figure 1). 


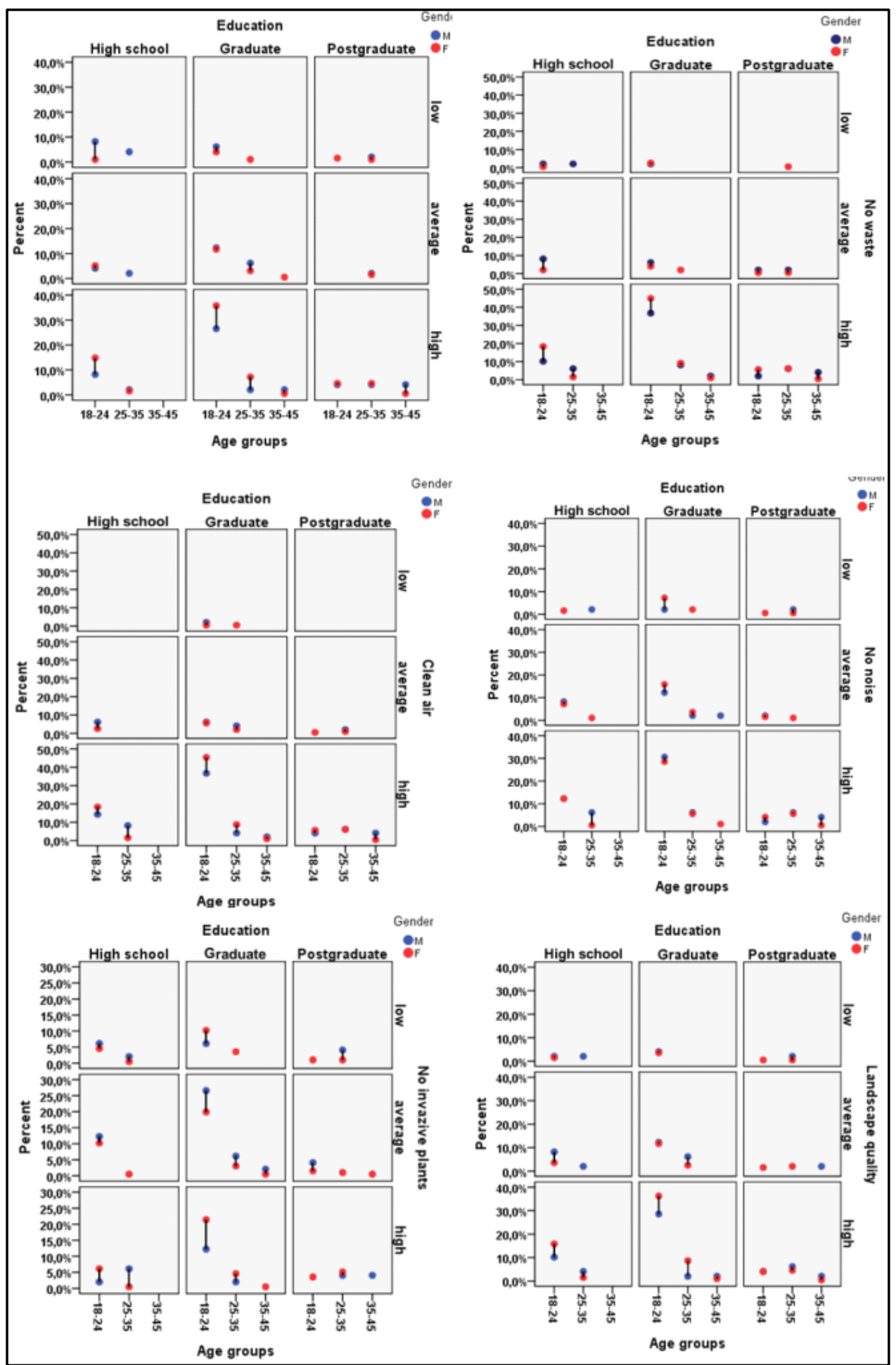

Figure 1. Differences in perception regarding the importance of environmental quality in choosing a vacation by gender, educational level, and age group. 


\section{Pro or cons-environmental behaviour and attitude}

Statistical tests present significance among socio-demographic characteristics (gender, education revenues) and variables for behaviours or attitudes of YGT in visited destinations (Table 2).

The YGT try to reduce their impact on the environment. Thus, about $91 \%$ of them practice appropriate litter disposal. At the same time, $45 \%$ of respondents correctly appreciate food consumption in restaurants, especially females, and those married with children, but more than half have no targets to avoid food waste. The higher the education, the more careful food management is, while revenues reveal contrasts in saving food options, equally positioning those with high or low incomes as less concerned with The issue of food waste is more strongly shown by those in the middle-income group or those who have families.

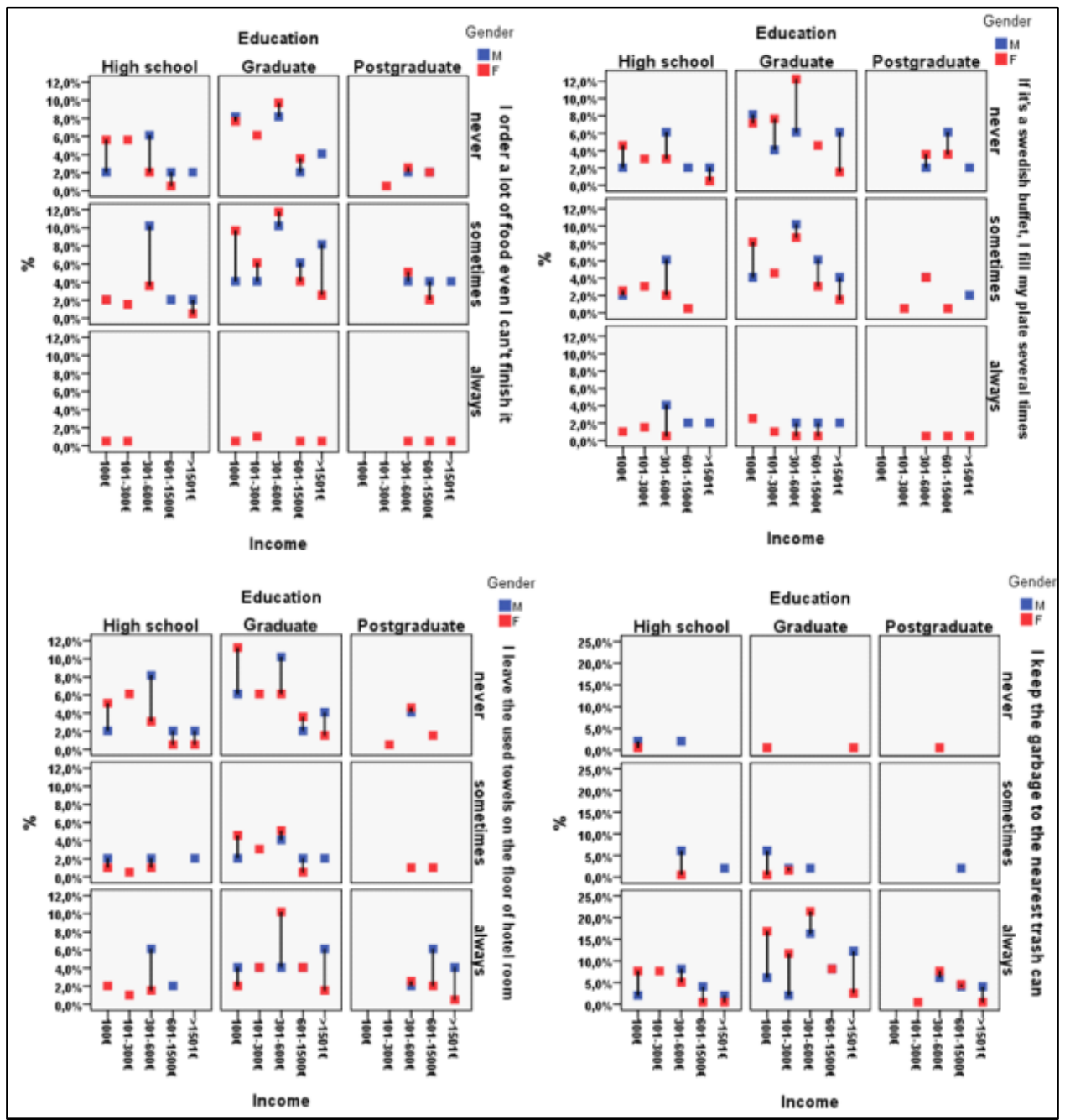

Figure 2. The YGT attitudes towards sustainability according to education, gender and income. 


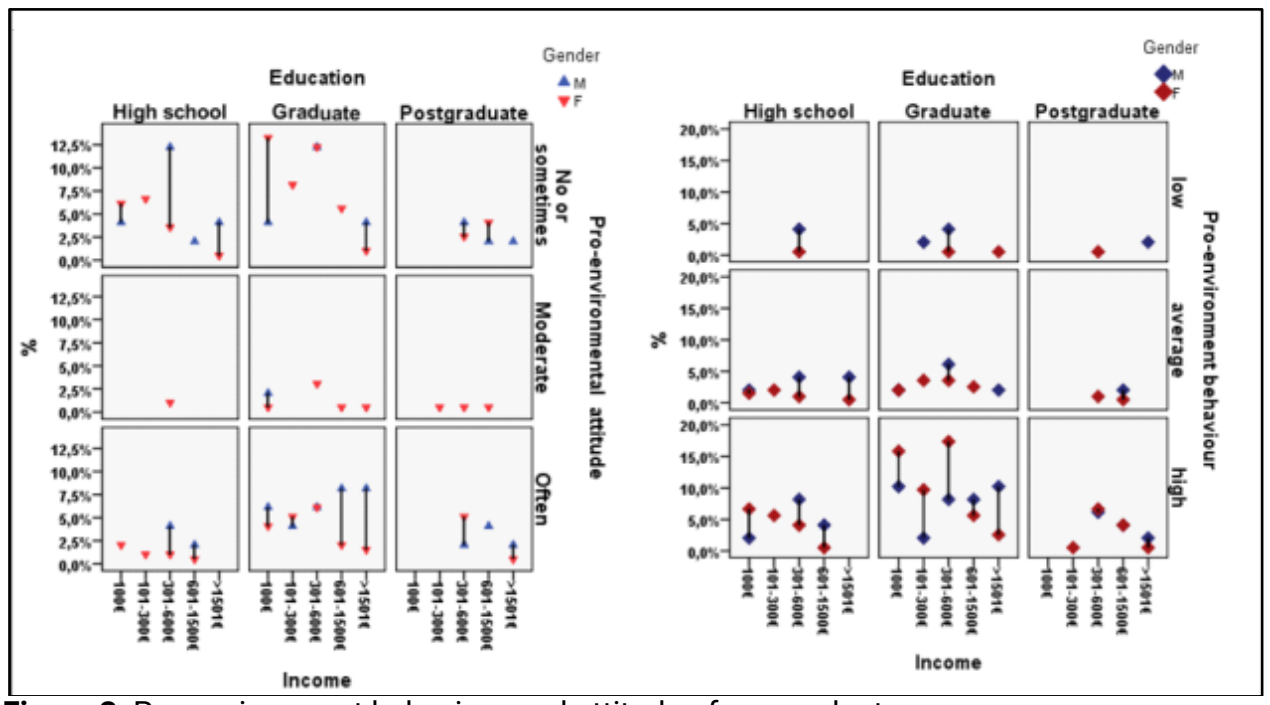

Figure 3. Pro-environment behaviour and attitude of respondents

The environmental attitude in accommodation room opposes the idea of sustainability in the case of about two-thirds of the sample group. Thus, interviewees care less about water consumption and the pollution caused by the use of detergents ignoring pro-environmental logos when they are inside hotels. However, a positive attitude towards waste management they produce is undeniable (Figure 2).

In sum, environmental behaviour is a strong behavioural trait of this generation, because $77 \%$ are those who declare themselves as pro-sustainability. Despite this, the attitude towards involvement in formal actions or private initiatives on environmental issues is recognised only by $40 \%$ of respondents, males, and people post-graduate level education being much more proactive (Figure 3).

Table 2. The attitude of GYT on environment quality in a destination. The relevant results of $F$, and $p<0.05$ in tests.

Items

\begin{tabular}{llll}
\hline \multicolumn{1}{c}{ Items } & $\begin{array}{c}\text { F (Laven/ } \\
\text { Fisher Test) }\end{array}$ & $\begin{array}{c}\text { Value } \\
\mathrm{p}<0.05\end{array}$ & Type of analysis \\
\hline I keep the litter until I can find a trash can & 40.488 & 0.001 & Independent \\
I order a lot of food even I can't finish it & 4.485 & 0.035 & simple T-test \\
Attitude to protect the environment & 3.420 & 0.001 & (gender) \\
Pro-environment behaviour & 8.655 & 0.004 & \\
Attitude to protect the environment & 3.877 & 0.022 & One-Way \\
I leave the towels I used on the floor of the & 3.664 & 0.027 & Anova \\
bathroom & & & (education) \\
I order a lot of food even I can't finish it & 2.304 & 0.059 & One-Way \\
I leave the towels I used on the floor of the & 3.597 & 0.007 & Anova \\
bathroom & & & (revenues) \\
\hline
\end{tabular}

Source: Selected from IBM output, SPSS v 20 


\section{Conclusions}

The YGT, as the main consumer of domestic tourism, can play an important role in choosing a sustainable direction for Romanian tourism. This study proves that young tourists' perception is confirmed by the behaviour, and therefore, the modelling of the tourist offer in Romania must pay more attention to the quality of a number of environment components, but also to the environment as a whole. If tourism would focus on the preservation of the total quality of the environment, it could increase Romania's attractiveness for both domestic customers and international arrivals. Thus, there is a need for simultaneous and permanent participation in achieving this goal on behalf of all actors involved in tourism and other related economic and social activities. This is a fundamental condition without which sustainable tourism becomes just a theoretical notion, an aspiration, and not a concrete reality.

Until the adoption of a system of certification for sustainable destinations, it is necessary to disseminate the pro-environmental information at the level of accommodation structures and public catering units, in order to correct some deficiencies in the education of tourists. Such information can also be passed to the younger generation. At the same time, measures are required to stimulate local communities in keeping tourist destinations clean and improving them in terms of infrastructure, in accordance with environmental legislation. As far as the hospitality staff is concerned, continuous training on the environmental aspects of their workplace becomes compulsory. Once acquired, these aspects of preserving the quality of the environment can be added to the image under which tourism is traded.

Given that each generation is the product of a period of formation, it is required that education be turned into a vector of change from a passive attitude to an active one, from a laisser-faire development to a proactive, positive one, because each individual can contribute to sustainable development in general and, implicitly, to sustainable tourism. Sustainable tourism is the agent of the long-term development of the society. The pro attitude of the young generation regarding the environment represents a preamble or an additional reason for the development of the Romania strategies, in general, and in the Romanian tourism industry in particular.

\section{References}

Băbăiță, C., Ispas, A., Pîrjol, F., (2010), “The tourist perception of the hospitality industry: Romania versus European Union”, Annals of Faculty of Economics, vol. 1, no 1, p. 248-252.

Bramwell, B. and Lane, B. (2010), "Sustainable tourism and the evolving roles of government planning", Journal of Sustainable Tourism, vol. 18, no. 1, p. 1-5.

Breaban, I.G. and Breaban, A.I. (2019), "Causes and Effects of Water Pollution in Romania", Water Resources Management in Romania, p. 57. 
Buckley, R., (2012), "Sustainable tourism: Research and reality", Annals of Tourism Research, vol. 39, no. 2, p. 528-546.

Budeanu, A. (2007), "Sustainable tourist behaviour-a discussion of opportunities for change", International Journal of Consumer Studies, vol. 31, no. 5, p. 499-508.

Buffa, F. (2015), "Young Tourists and Sustainability. Profiles, Attitudes, and Implications for Destination Strategies", Sustainability, vol. 7, p. 14042-14062.

Cohen, J. (1992), "Statistical Power Analysis, Current Directions", Psychological Science, vol. 1, no. 3, p. 98-101.

COM (2007), "Communication from the Commission - Agenda for a sustainable and competitive European tourism", COM/2007/0621.

Doroftei, M. and Anastasiu, P. (2014), "Potential impacts of climate change on habitats and their effects on invasive plant species in Danube Delta Biosphere Reserve", in S. Rannow and M. Neubert (eds.) Romania. Managing Protected Areas in Central and Eastern Europe Under Climate Change, p. 267-278, Springer, Dordrecht.

Dumitrașcu, M., Kucsicsa, G., Dumitrică, C., Popovici, E.A., Vrînceanu, A., Mitrică, B., Mocanu, I. and Șerban, P.R., (2020), "Estimation of Future Changes in Aboveground Forest Carbon Stock in Romania. A Prediction Based on Forest-Cover Pattern Scenario", Forests, vol. 11, no. 9, p. 914.

Filip, S. and Cocean, P. (2012), "Urban industrial brownfields: Constraints and opportunities in Romania", Carpathian Journal of Earth and Environmental Sciences, vol. 7, no. 4, p. 155 - 164 .

Gardiner, S., Grace, D. and King, C. (2014), "The Generation Effect: The Future of Domestic Tourism in Australia", Journal of Travel Research, vol. 53, no. 6, p. 705-20.

Gavreliuc, A. and Ciobotă, C.I. (2013), "Culture and Self-Construal: Implications for the Social Cognitions of Young Cohorts in Romania", Procedia - Social and Behavioral Sciences, vol. 78, p. 270-274.

Iordache, S,. and Dunea, D. (2013), "Cross-spectrum analysis applied to air pollution time series from several urban areas of Romania", Environmental Engineering and Management Journal, vol. 12, no. 4, p. 677-684.

Levei, E., Frentiu, T., Ponta, M., Senila, M., Miclean, M., Roman, C. and Cordos, E., (2009), "Characterisation of soil quality and mobility of $\mathrm{Cd}, \mathrm{Cu}, \mathrm{Pb}$ and $\mathrm{Zn}$ in the Baia Mare area Northwest Romania following the historical pollution", International Journal of Environmental Analytical Chemistry, vol. 89, p. 635-649.

Lu, J. and Nepal, SK, (2009), "Sustainable tourism research: an analysis of papers published in the Journal of Sustainable Tourism", Journal of Sustainable Tourism, vol. 17, no. 1, p. 5-16.

Manea, G., Nae, M., Matei, E., Vijulie, I. and Tîrlă, L. (2013), "Raising Awareness of Volunteer Tourism: Experiencing the Volunteer Tourism among Students and Young Researchers", GeoJournal of Tourism and Geosites, vol. 12, no. 2, p. 120-128.

Matei, E. (2016), Turism și dezvoltare durabilă, Editura Universitară, București.

Matei, D. (2018), "Conflicts in tourism and sustainable development in Moieciu de Sus village, Moieciu Resort", JETA, vol. 6, no. 1, p. 32-42. 
Matei, E., Stănciou, F.-A., Vijulie, I., Manea, G. and Cuculici, R. (2019), "Attractiveness and Competitiveness of the Romanian Carpathian Mountains Destination: A study of Perception of Generation Y", Journal of Environmental and Tourism Analyses, vol. 7, no. 1, p. 5-18.

Nafi, SM and Ahmed, T. (2017), "Sustainable tourism in Saint Martin Island: An observation on young tourist perception and awareness level", IOSR Journal of Humanities and Social Science, vol. 22, no. 10, p. 73-80.

National Institute of Statistics, (2020). Tempo-online series. 12 September 2020, http://statistici.insse.ro.

Nicholas, L. and Thapa, B. (2010), "Visitor perspectives on sustainable tourism development in the Pitons Management Area World Heritage Site, St. Lucia", Environment, Development, and Sustainability, vol. 12, p. 839-857.

Nicula, V., Spanu, S. and Neagu, RE (2013), "Regional tourism development in Romania-consistency with policies and strategies developed at EU level", Procedia Economics and Finance, vol. 6, p. 530-541.

Nusair, K.K., Parsa, H.G. and Cobanoglu, C. (2011), "Building a model of commitment for Generation Y: an empirical study on e-travel retailers", Tourism Management, vol. 32, p. 833-843.

Nuță, F.M., Tabără, N., Nuță, A.C. and Crețu, C. (2015), "An assessment upon the environmental policy in Romania", Ekonomska istraživanja, vol. 28, no. 1, p. 641-649.

Oncioiu, I., Dănescu, T. and Popa, M.A. (2020), "Air-Pollution Control in an Emergent Market: Does It Work? Evidence from Romania", International Journal of Environmental Research and Public Health, vol. 17, no. 8, p. 26-56.

Petrişor, A.I. (2015), "Using CORINE data to look at deforestation in Romania: Distribution \& possible consequences", Urbanism, vol. 6, p. 83-90.

Reeves, T.C. and Oh, E.J. (2008), "Do generational differences matter in instructional design", IT Forum, p. 1-25.

Romocea, T., Oneț, A., Sabău, N.C., Oneț, C., Herman, G.V. and Pantea, E. (2018), "Change of the groundwater quality from industrial area Oradea, Romania, using geographic information systems (GIS)", Environmental Engineering E Management Journal (EEMJ), vol. 17, no. 9, p. 2189-2199.

Ruhanen, L., Weiler, B., Moyle, B.D. and McLennan, C.L.J. (2015), "Trends and patterns in sustainable tourism research: A 25-year bibliometric analysis", Journal of Sustainable Tourism, vol. 23, no. 4, p. 517-535.

Scheyvens, R. (2011), "The Challenge of Sustainable Tourism Development in the Maldives: Understanding the Social and Political Dimensions of Sustainability", Asia Pacific Viewpoint, vol. 52, p.148-164.

Teodorov, A.V., Mureșan, M.L., Dinu, DM and Dinu, AC (2020), "Digital marketing on destination sustainability Study case: Romanian Ecotourism", Proceedings of the International Conference on Business Excellence, vol. 14, no. 1, p. 859-867.

Ungureanu, G., Ignat, G., Leonte, E., Costuleanu, C.L., Jităreanu, S., Donosă, D., Soare, E.T. and Sandu, I.G. (2018), "Management of urban organic solid waste applied in Romanian metropolitan city", Revista de Chimie, vol. 69, no. 6, p. 1585-1592. 